\title{
ANTARA MAKKAH, BASRAH DAN KEMERDEKAAN STUDI KONSTRUKSI HISTORIS PENDIDIKAN ISLAM ERA KLASIK HINGGA MODERN
}

\author{
M. Muja6 \\ Pascasarjana UIN Maulana Malik Ibrahim Malang, Telp. 08123292911, \\ email: mujab66@gmail.com
}

\begin{abstract}
Islamic Education at first period was showed its superiority. It was proved by the emergency of superior, dinamic and creative generation. The generation from companions of the prophet, tabi'in and tabi'it tabiin are a sturdy generation, have a high comitment for moral values of Islam. Whereas on the pre-modern, Islam was suffered a decrease. Its quite alarming setback. Its period of deteriorate. This periode was identified as time of the demise of the Islamic struggle. So, education was not incised achievement then previous generations.
\end{abstract}

Pendidikan Islam pada masa periode awal/klasik telah menunjukkan keunggulannya, yaitu dengan dibuktikannya muncunya generasi yang unggul, dinamis, dan kreatif. Generasi Sahabat, Tabi' in, dan masa tabi'tabi'in merupakan generasi yang tangguh, memiliki komitmen yang tinggi terhadap nilai-nilai ajaran risalah Muhammad. Sedangkan pada masa pra modern, dunia Islam dikejutkan oleh kemunduran yang cukup memprihatinkan. Itulah jaman kemunduran. Jaman ini diidentifikasi sebagai jaman padamnya api perjuangan Islam. sehingga dunia pendidikanpun tidak banyak mencatat prestasi gemilang sebagaimana generasi-generasi sebelumnya.

Key words: Islamic education, history

\section{Pendahuluan}

Pendidikan Islam memiliki watak dan corak yang selalu berkembang dengan sangat dinamis. Hal itu telah dibuktikan dalam perjalanan sejarah 
panjangnya. Jika dulu Barat belajar ke Islam, kini malah terjadi titik balik (turning point). Dalam putaran sejarah saat ini, Islam telah tertinggal jauh. Barangkali jika umat Islam menginginkan kemajuan, maka peniruan cara barat dalam menyerap ilmu dari Islam, menjadi sebuah keniscayaan. Melalui pembacaan sejarah yang kritis, umat Islam mempunyai potensi besar dalam pelacakan, pembandingan hingga pada akhirnya melakukan transformasi keilmuan secara besar-besaran terhadap ilmu pengetahuan. Di era saat ini, pendidikan Islam dihadapkan pada isu globalisasi yang semakin membiaskan nilai, norma, dan etika. Hal hal tersebut menjadi tantangan terberat yang harus dihadapi. Titik pergumulan sejarah pendidikan Islam merupakan satu kesatuan yang berkesinambungan. Titik paling awal dalam sejarah pendidikan Islam merupakan pondasi strategis pembentukan konstruksi kesadaran umat Islam dalam menyerap pendidikan. Masa-masa awal ini dibagi dalam dua bagian, fase Makkah dan fase Madinah.

Fase Makkah adalah fase pembinaan awal. Saat itu Nabi Muhammad fokus dan berkonsentrasi agar umat Islam belajar membaca. Ajakan membaca disini bukan saja membaca yang tersurat dalam tulisan tapi juga membaca alam yang bertujuan agar memperkokoh akidah umat Islam. Tauhid sebagai materi utama pada fase Makkah dimaksudkan untuk memurnikan agama Ibrahim yang telah banyak diselewengkan kaum jahiliyah pada waktu itu. Sejalan dengan penanaman tauhid yang bertujuan untuk menanamkan keimanan, masyarakat Makkah juga diajak untuk belajar baca tulis sesuai dengan perintah ayat pertama yang diturunkan kepada Nabi Muhammad. Kemampuan membaca dan menulis para sahabat kelak menjadi modal untuk mengembangkan peradabannya yang selama kurang lebih seribu tahun umat Islam mengalami kejayaan dan memimpin dunia.

Pendidikan di fase Makkah yang lebih menekankan pada pemurnian akidah (tauhid) dan ibadah adalah menunjukkan betapa pentingnya penanaman akidah dalam pendidikan sebelum memulai dengan pendidikan yang lain. Sebab, akidah merupakan dasar yang di atasnya akan dibangun nilai-nilai kejujuran, kesetiaan, kewiraan, yang gilirannya menjadi modal perjuangan dalam mendakwahkan risalah Islam. Banyak yang bisa dicatat dalam fase ini, kurikulum pada masa pendidikan Rasulullah adalah al Quran itu sendiri. Di mana Allah mewahyukan sesuai dengan kondisi dan situasi, kejadian dan peristiwa yang dialami oleh umat Islam saat itu. Terobosan penting dalam pendidikan Islam saat itu. Hal yang terpenting yang harus kita catat adalah Rasulullah menganjurkan belajar baca tulis dan mempelajari bahasa asing. 
Fase selanjutnya dikategorikan sebagai fase Madinah. Kegiatan pendidikan difokuskan pada masjid-masjid yang menjadi sentral kegiatan pembinaan dan pembelajaran para sahabat. Masjid juga merupakan tempat yang multifungsi. Di samping fungsi utamanya untuk kegiatan salat berjamaah, masjid Madinah juga digunakan untuk proses ajaran Islam dan tempat membahas berbagai peristiwa politik. Bahkan, masjid juga menjadi tempat tinggal para sahabat nabi yang miskin (ashab shufah). Catatan penting dari pendidikan fase Makkah dan Madinah adalah keberhasilan Nabi Muhammad dan pengikutnya melahirkan ummat (masyarakat, bangsa) baru. Fase tersebut menjadi lompatan terpenting umat Islam saat itu, sebab mampu memunculkan rasa kebangsaan Arab di antara para sahabat. Sejarawan kondang Antony Black mengomentarinya sebagai berikut:

"Apa yang terjadi di masa itu bisa dijelaskan dengan melihatnya sebagai sesuatu yang bersifat spiritual dan sekaligus politik. Tujuan Muhammad persisnya adalah menunjukkan kepada konsep ketuhanan sebelumnya, meskipun didasarkan atas prinsip kemanusiaan gagal bertahan ketika berhadapan dengan masalahmasalah kekuasaan. Konflik-konflik petama dalam Islam, misalnya tentang siapa yang harus memimpin dan bagaimana cara seorang pemimpin dipilih, merupakan ujian politik pertama bagi umat Islam" (Black, 2001: 37).

Sisi lain kecemerlangan dalam konstruksi pendidikan yang terbangun dalam fase ini adalah munculnya gagasan kebangsaan. Semangat kebangsaan yang muncul adalah adanya pengakuan kesetaraan antara muslim Arab dan muslim non-Arab. Muslim non-Arab disambut dengan baik. Bahkan secara moral, mereka diperlakukan memiliki kesamaan hak dan kewajiban yang sama dengan orang Arab. Pusat konsentrasi madrasah yang paling terkenal, selain di Makkah dan Madinah adalah madrasah Basrah. Dari madrasah ini muncul tokoh-tokoh besar seperti Abu Musa al Asy'ari yang ahli fiqih dan Anas bin Malik yang masyhur dalam bidang Hadits. Madrasah Basrah memunculkan pula tokoh Hasan al Basri yang ahli Tasawuf dan dianggap sebagai perintis mazhab ilmu kalam di lingkungan mazhab ahli sunnah wal jama'ah. Tokoh lain yang terlahir dari madrasah itu adalah Ibnu Sirin. Ia menjadi tokoh yang tercatat sebagai ahli Hadits dan Fikih (Zuhairini, 1994: 64). Pada fase yang hampir bersamaan juga berdiri madrasah di Damsik (Syiria), di Iskandariyah (Mesir) dan di tempat-tempat lain yang menjadi konsentrasi umat Islam pada waktu itu.

Pada masa selanjutnya, konsentrasi pendidikan Islam diperluas hingga kuttab. Di beberapa kawasan Islam saat itu, kuttab merupakan tempat belajar para 
siswa untuk mengenal baca tulis, yang kemudian meningkat pada pembelajaran al Quran dan pengetahuan agama dasar. Pada umumnya kuttab-kuttab dibangun di samping masjid. Hal ini dikarenakan adanya kekhawatiran bila menjadi satu dengan masjid akan mengotori tempat ibadah tersebut. Fungsi kuttab dalam kondisi sekarang menyerupai taman pendidikan al Quran (TPA).

Pada era selanjutnya, abad ke-8, kuttab tidak lagi hanya mengajarkan agama, tapi juga pengetahuan umum. Hal ini menunjutkkan kuttab yang dulunya tertutup akan tetapi setelah terjadinya perluasan Islam dan persentuhan dengan peradaban lain berubah menjadi lembaga pendidikan yang terbuka terhadap pengetahuan umum, termasuk filsafat (Nizar, 2007: 27). Pembelajaran dan pendidikan yang mendominasi saat itu masih bersifat klasikal. Hal ini sama dengan model pendidikan maktab/kuttab pada era awal pendidikan agama Islam di Indonesia, dimana kuttab hanya mengajarkan al Quran dan ilmu-ilmu agama dasar saja. Tidak berkembang sebagaimana kuttab pada era awal Islam. Dari sisi waktu yang digunakan, kuttab menerapkan waktu belajar dari pagi hingga sore. Hal ini serupa dengan sistem fullday-school yang bermunculan di Indonesia. Selain kuttab, masjid juga digunakan sebagai tempat pendidikan agama.

Di sini ada dua kategori masjid, masjid jami' dan masjid biasa. Kapasitas masjid jami' biasanya lebih sedikit daripada jumlah masjid non-jami'. Sebagai contoh, pada abad ke-11 di kota Baghdad hanya terdapat enam masjid jami', sedangkan jumlah masjid non-jami' berjumlah ratusan. Masjid jami' umumnya dikelola oleh pemerintah dan digunakan sebagai sarana untuk menyelenggarakan pendidkan Islam melalu sistem khalaqah. Inilah yang ditiru oleh khalaqah-khalaqah di lingkungan pesantren non klasikal (Nizar, 2007: 117). Yang perlu menjadi catatan di sini, di masjid-masjid tersebut juga menyediakan makanan gratis, klinik obat-obatan gratis, dan bahkan dokterdokter yang siap memberikan pelayanan gratis tanpa membeda-bedakan suku maupun agama.

Kemunculan madrasah merupakan bentuk lain dari lembaga pendidikan agama pada masa awal Islam. Meskipun, sebagai sebuah lembaga, madrasah muncul paling akhir dibanding lembaga lainnya. Hal ini disebabkan karena istilah madrasah baru muncul pada awal abad ke-10. Ini menunjukkan tumbuhnya lembaga-lembaga pendidikan Islam secara bertahap; (1) masjid, (2) kuttab/ maktab, (3) madrasah. Eksistensi madrasah sebagai lembaga pendidikan dalam sejarah peradaban Islam memiliki karakter mendasar. Kehadirannya merupakan keinginan masyarakat, didanai oleh masyarakat, dan dikelola oleh 
masyarakat setempat. Jadi, madrasah muncul karena kesadaran yang tumbuh dari masyarakat yang ingin mengelola pendidikan secara mandiri. Madrasah yang didirikan pertama kali dalam catatan sejarah adalah madrasah Baihaqiyah yang didirikan oleh Abu Hasan al Baihaqi (414 H.) di kota Nisabur sebelum abad ke-10 selisih lebih satu abad sebelum berdirinya madrasah Nizamiyah di kota yang sama (Nizar, 2007: 121).

Madarasah Nizamiyah yang digagas pendiriannya oleh Nizam al Mulk, seorang menteri dari dinasti Saljuk berlokasi di Baghdad dan Nisabur. Kedua madrasah ini pernah menjadi tempatnya Hujjatul Islam al Ghazali mengajar murid-muridnya. Di samping itu, ada madrasah-madrasah lain, seperti madrasah Nashiriyah, madrasah Saifiyah, madrasah Fadhiliyah yand dibangun pada masa dinasti Fatimiyah pada masa pemerintahan Khalifah al Khafiz al Fathimi. Madrasah yang terakhir memiliki perpustakaan dengan koleksi sebanyak kurang lebih 100.000 kitab. Pada umumnya lokasi perpustakaan-perpustakaan tersebut dibangun di samping masjid yang secara bebas dapat dimanfaatkan oleh umum, termasuk menyediakan alat tulis dan kertas gratis kepada siapa saja yang membutuhkan. Barangkali ini salah satu yang perlu dicontoh dalam mengembangkan pendidikan Islam di era kontemporer. Madrasah sebagai sebuah institusi pendidikan, pada umumnya memiliki kurikulum yang lebih luas daripada kuttab/maktab. Kurikulumnya meliputi ilmu-ilmu jenjang lebih tinggi, seperti tafsir Hadits, fikih, dan ilmu-ilmu bahasa dan kesusasteraan. Madrasah didirikan juga digunakan untuk menghidupkan mazhab-mazhab Sunni atau Syi'ah. Pada era selanjutnya, keberadaaan madrasah juga tidak lepas dari kepentingan pemerintah, termasuk untuk mempertahankan ideologi penguasa.

Perkembangan pendidikan Islam terus berkembang ketika arah kekuasaan politik dipegang beberapa dinasti. Kemajuan bidang pendidikan, sebagaimana diungkap oleh Nasr, diawali oleh munculnya institusi-institusi pendidikan yang telah memainkan peran penting dalam perkembangan seni dan ilmu pengetahuan. Sebuah institusi pendidikan terpenting pada waktu itu adalah Bait al Hikmah yang didirikan oleh khalifah al Makmun (Nasr, 1978: 93). Para sarjana dan pakar bekerja keras menerjemahkan berbagai literatur dari berbagai bahasa asing ke dalam bahasa Arab. Literatur dari bahasa Yunani, Parsi, maupun Sanskrit telah diterjemahkan ke dalam bahasa Arab. Kegiatan ini berlangsung pada abad ketiga sampai empat hijriah. Di antara sarjanasarjana yang dianggap paling berjasa pada waktu itu antara lain adalah Thabit ibnu Qurrah, Hunain ibnu Ishaq, dan Ibnu Muqaffa. Demikian hebatnya 
kerja keras mereka sehingga sampai sekarang, karya-karya besar filsuf Yunani seperti Aristoteles, Phytagores, Plato, dan filsuf Yunani lainnya lebih banyak ditemukan dalam bahasa Arab dari pada yang terulis dalam bahasa Eropa modern.

Nizamul Mulk merupakan salah seorang menteri dinasti Saljuk yang menggagas pendirian dan pendanaan madrasah. Ia menyarankan agar pendanaan lembaga pendidikan Islam itu ditanggung penuh oleh keuangan negara. Meskipun, pada saat itu, telah bermunculan madrasah-madrasah swasta yang dikelola oleh perorangan, misalnya madrasah yang didirikan oleh Ridwan al Wahsyi di Iskandariyah pada tahun $532 \mathrm{H} / 1137 \mathrm{M}$ yang bermazhab Syafi'i dan madrasah yang didirikan oleh Ibnu Salar, wazir pada masa dinasti Fathimiyah di Mesir. Tradisi pendidikan muslim juga mengenalkan apa yang disebut ijazah. Seorang murid yang telah dianggap cukup memilki ilmu setelah berguru kepada seorang syaikh akan mendapatkan ijazah dalam bidang ilmu yang ditekuninya, misalnya bidang Tafsir, bidang Hadits, bidang Nahwu dan lainnya. Bukan hanya dalam bidang ilmu agama saja, tetapi pemberian ijazah juga diberlakukan bagi para mahasiswa yang menuntut ilmu kedokteran dan ilmu-ilmu yang lain. Bahkan untuk ilmu kedokteran ijazah tidak diberikan dengan mudah, tetapi harus melalui beberapa tahapan. Sebagai contoh, pada saat itu, mahasiswa kedokteran diharuskan melakukan riset terlebih dahulu dalam ilmu yang diminati. Tahapan selanjutnya mahasiswa diuji oleh dokter senior. Tahapan terakhir adalah mahasiswa kedokteran tersebut diberikan ijazah (ijin praktek). Pemberlakuan ijazah ini dimulai sejak masa Khalifah al Muqtadir pada masa dinasti Abbasiyah.

Perkembangan yang sama juga terjadi di wilayah pusat kekuasaan Islam di wilayah barat. Kawasan yang dimaksud meliputi kekuasaan Dinasti Umayyah (138-418H/756-1027) di Cordoba, Granada. Di kota-kota lainnya juga terjadi ledakan ilmu pengetahuan yang muncul dari madrasah/universitas yang menjadi simbol kecemerlangan pendidikan Islam di wilayah itu. Hal itu sekaligus memberikan sumbangan khusus bagi kemajuan Eropa pada abad pertengahan. Keunggulan universitas yang dibangun pada era itu antara lain kurikulumnya meliputi bidang astronomi, kedokteran, teologi, filsafat, astronomi, metafisika, aritmatika pertanian, dan lain-lain. Sementara pada saat yang sama juga dibuka madrasah yang mengkhususkan dalam bidang ulum al Quran, ulum, al Hadits, dan bidang ilmu-ilmu bahasa.

Perkembangan pendidikan di Cordoba disetarakan sebagai pendidikan liberal klasik, artinya hampir semua cabang ilmu dipelajari, diajarkan, dan 
dikaji, sehingga muatan kurikulumnya digambarkan sebagaimana kurikulum sekarang di college-college Inggris dan Perancis. Dalam beberapa hal, sekolahsekolah tinggi di Amerika memiliki hubungan dengan madrasah-madrasah di Cordoba. Yang cukup mengherankan, ternyata madrasah-madrasah internasional itu dibuka bukan hanya untuk kaum muslimin saja, tetapi juga juga bagi komunitas agama lain meskipun pengawasan tertinggi dari lembaga-lembaga pendidikan tersebut dipegang oleh para ulama.

\section{Kolonialisme dan Titik Balik Pendidikan Islam}

Perkembangan pendidikan islam di masa kolonialisme mengalami perubahan. Pada masa tersebut, pendidikan Islam mengalami dualisme dalam sistem, sementara pada awal agama Islam hanya mengenal satu sistem pendidikan. Model pendidikan dikotomi ini dalam perspektif sejarah berawal dari terputusnya umat Islam dari arus sains dan teknologi pada awal akhir abad ke-18. Kedatangan Barat dengan ditandai kolonialisme berimplikasi kepada meningkatnya kesadaran umat Islam untuk mempertahankan kemandirian intelektual dan politiknya. Penetrasi Barat ke dunia Islam membuat kaum muslimin selalu bersikap curiga terhadap segala apa yang dibawa oleh Barat, termasuk sistem pendidikannya. Akan tetapi, sikap penolakan ini lambat-laun menyadarkan umat Islam karena mengakibatkan kemunduran pada semua bidang baik budaya, politik, maupun ekonomi.

Peristiwa di seputar pasca kejatuhan kerajaan Mughol di India membuat banyak madrasah-madrasah ditutup. Hal itu dikarenakan madrasah kurang diminati masyarakat disebabkan pemerintah Inggris tidak pernah mengakui ijazah dari lembaga-lembaga pendidikan Islam. Kondisi demikian itu, membuat Sir Sayid Ahmad Khan membuka Aligarh Muslim University pada tahun 1875 meskipun pada awalnya keberadaannya membuahkan berbagai kritik. Langkah terobosan Khan nyatanya memang tepat. Sebab, hampir semua pospos penting pemerintahan Pakistan generasi pertama diisi oleh para alumni Aligarh. Seandainya, Khan tidak mendirikan Aligarh, tentu Jamia Millia Islamia tidak akan pernah berdiri karena universitas tersebut didirikan oleh para alumni Aligarh.

Di negara-negara bekas jajahan Barat seperti Mesir, Tunisia, Maroko dan Asia Selatan, sikap umat Islam juga pro dan kontra soal pendirian sekolah model Barat. Karena pendirian sekolah semacam itu dianggap bukan warisan tradisi Islam. Melihat hal itu, sesungguhnya Barat dulu juga bersikap curiga terhadap ilmu pengetahuan yang datang dari Islam. Sejak abad ke-12, Negara 
Barat mulai mengenal ilmu pengetahuan Islam meskipun dengan stigma atau halangan psikologis yang luar biasa karena menganggap sebagai ilmunya orang-orang kafir. Perasaan serupa juga diendap oleh kaum Islam. Dalam hal ini, orang-orang Islam mengalami fobia anti-Barat. Selama hampir 200 tahun mereka menolak ilmu pengetahuan dari Islam. Karena bagi yang menerima akan mendapatkan kutukan dari gereja. Untuk dapat menerimanya, Barat perlu waktu masa 400 tahun, yaitu dari abad ke-12 sampai abad ke-14 yang merupakan masa adaptasi Barat terhadap ilmu pengetahuan Islam. Dari abad ke-14 sampai ke-16, mereka mulai merasa aman dengan ilmu pengetahuan dari Islam. Baru pada abad ke-16 ke depan mereka dengan sepenuhnya menerima ilmu pengetahuan dari Islam dan mengembangkannya sendiri sehingga pada saat itu Islam tertinggal sampai sekarang. Jadi Islam mulai ditinggal oleh Barat pada akhir abad 16 dan awal 17 dilambangkan dengan jatuhnya Malaka ke tangan Portugis pada tahun 1511, atau 400 tahun setelah al Ghazali wafat.

Berbicara tentang Pendidikan Islam di Indonesia sesungguhnya telah mengalami proses yang panjang. Tepatnya dimulai sejak masa orde lama melalui surat edaran Ki Hajar Dewantara serta Penetapan Bersama Menteri Agama dan Menteri Pendidikan, Pengajaran dan Kebudayaan No. 1285/K.7 dan 1142/BHG A Tanggal 12 Desember 1946 yang kemudian diperbaharui dengan Peraturan Bersama No. 17678/ Kab dan K/9180 tanggal 16 Juli 1951. Selanjutnya melalui Tap MPR no II/MPRS/1966 secara tegas telah menetapkan bahwa pendidikan agama diajarkan sebagai mata pelajaran di sekolah dasar sampai perguruan tinggi.

Dari sisi varian dan jenjangnya pendidikan Islam di Indoneia dapat dikategorisasikan menjadi lima kelompok:

1. Pondok pesantren, Madrasah Diniyah, yang disebut sebagai pendidikan keagamaan.

2. Madarsah dan pendidikan lanjutanya seperti UIN, IAIN, DAN STAIN.

3. Pendidikan usia dini/taman kanak-kanak, sekolah/perguruan tinggi yang diselenggarkan oleh yayasan dan organisasi Islam.

4. Pelajaran agama Islam di sekolah/madrasah/perguruan tinggi sebagai suatu mata pelajaran/mata kuliah/program studi.

5. Pendidikan Islam dalam keluarga dan tempat-tempat Ibadah, seperti majlis taklim, dll.

Selanjutnya dalam dua dekade terakhir pendidikan Islam telah masuk dalam sistem pendidikan nasional yang ditandai oleh adanya tiga perubahan 
mendasar. Terbitnya UU No. 2 tahun 1989 yang memposisikan madrasah sebagai pendidikan umum berciri khas Islam yang selanjutnya melalu UU No. 20 tahun 2003 tentang UU Sisdiknas kedudukannya disamakan dengan sekolah umum lainnya. Sedangkan PTAIN memiliki kedudukan yang sama dengan pendidikan perguruan tinggi umum lainnya dimana pendiriannya ditetapkan berdasarkan Keputusan Presiden (sumber: Renstra Ditjen Pendidikan Islam 2009). Sedangkan dari sisi jenjangnya Pendidikan Islam yang meliputi pendidikan dasar, dan menengah, yakni SD, MI, SMP, MTs dan bentuk lain yang sederajat untuk pendidikan dasar, serta SMA, SMK, MA, MAK dan bentuk lain yang sederajat untuk pendidikan menengah secara jelas didudukkan dalam peraturan perundang-undangan yang mengatur tentang penyelenggaraan pendidikan di Indonesia pasal 17 dan 18 UU 20 Tahun 2003. Hal ini mempertegas bahwa pendidikan Agama dengan semua jenjangnya secara kelembagaan memiliki kedudukan yang sama dengan pendidikan umum lainnya.

Sistem Pendidikan di Indonesia merupakan perpaduan antara warisan pendidikan Belanda di satu sisi, dan pendidikan tradisional yang dilembagakan dalam bentuk pesantren atau madrasah. Munculnya dualisme model pendidikan di Indonesia telah mengakibatkan dilema tersendiri. Ini artinya para pendiri negara melalui amanat UUD 1945 pasal 31 ayat 2 yang dinyatakan bahwa, "Pemerintah mengusahakan dan menyelenggarkan satu sistem pengajaran nasional yang diatur dengan undang-undang," telah meninggalkan pekerjaan tersendiri bagi generasi selanjutnya. Akan tetapi jika dilihat dari sisi historis, pendidikan Islam menurut the funding father, Hatta, didasari oleh pentingnya agama sebagai salah satu tiang penyangga pada kebudayaan bangsa. Lebih lanjut Hatta menyatakan, perlunya membangung masyarakat Indonesia yang kokoh yang dalam hal ini tidak mungkin dilakukan tanpa melibatkan Islam. Dengan kata lain, Hatta sangat menyadari hubungan positif antara pemahaman Islam dengan pembangunan masyarakat Indonesia. Oleh sebab itu, menurut Hatta dalam memorandumnya yang ditulis pada tahun 1945 menyatakan bahwa lembaga-lembaga pendidikan Islam, seperti pesantren dan madrasah telah tumbuh di Indonesia sejak lima abad yang lalu. Namun demikian, menurutnya, lembaga-lembaga pendidikan Islam tersebut hanya mengajarkan agama Islam pada tingkat menengah. Sedangkan, kajian Islam inklusif memerlukan pemikiran yang mendalam. Ia menilai, Islam harus dikaji secara kritis dan dinamis. Pengkajian Islam model demikian perlu wawasan yang luas di antaranya melalui pendekatan historis, filosofis, dan sosiologis.

Ide mengajak umat Islam untuk ikut mengisi kemerdekaan ini, menurut 
Hatta, harus ada pengajaran tentang hukum-hukum negara. Dengan alasanalasan sebagaimana disebutkan tadi, maka Hatta dan Sutiman menggagas pendirian Sekolah Tinggi Agama Islam yang baru terlaksana pada tahun 1946 yang kemudian disebut Sekolah Tinggi Islam (STI). Belakangan STI berubah nama menjadi Universitas Islam Indonesia (UII). Inilah awal mula sekolah tinggi Islam di Indonesia. Pendirian sekolah tinggi Islam dimaksudkan sebagai upaya mencerdaskan umat Islam agar mereka ikut menjadi bagian dalam membangun negara yang berwawasan luas, memiliki pemahaman Islam secara lebih komprehensif, dan memiliki wawasan kebangsaan dan memahami hukum ketatanegaraan.

Jika dikaitkan dengan munculnya radikalisme di dunia Islam atau kebangkitan Islam politik, maka tantangan pertama pendidikan Islam di Indonesia baik pendidikan di lingkungan pondok pesantren maupun perguruan tinggi adalah mengatasi radikalisme yang berkembang demikian pesatnya. Dalam konstelasi politik Indonesia, masalah radikalisme Islam telah makin membesar disebabkan pendukungnya juga makin meningkat. Agaknya kearifan para ulama semacam KH Hasyim Asya'ari, KH Wahab Hasbullah, dan kiai-kiai yang lain dalam menetapkan kurikulum pesantren dengan kitab kuningnya telah terbukti bahwa kitab-kitab itu tidak dipilih secara sembarangan. Demikian juga pelestarian kurikulum pesantren warisan para kiai itu yang hingga kini terbukti mampu meredam radikalisme. Ini tidak kalah pentingnya dengan pembaharuan pemikiran Islam yang dikembangkan di Perguruan Tinggi Islam. Oleh sebab itu, terjadinya kecenderungan melakukan sintesa antara pendidikan pesantren dan perguruan tinggi yang terjadi akhir-akhir ini merupakan sintesa yang banyak dirindukan output-nya oleh masyarakat.

Harapan besar terhadap peningkatan kualitas pendidikan Islam disematkan kepada pendirian Institut Agama Islam Negeri (IAIN). Berdiri pertama kali tahun 1950 yang waktu itu diberi nama Perguruan Tinggi Agama Islam Negeri (PTAIN), tujuan utama lembaga pendidikan Islam ini adalah untuk menyelenggarakan pendidikan tinggi Islam yang menjadi pusat pengembangan dan pendalaman pengetahuan agama Islam. Selain itu ditujukan pula untuk menghasilkan ahli-ahli agama Islam untuk mengisi kebutuhan masyarakat dan negara. Pada awalnya IAIN hanya berada di dua kota, yaitu Jakarta dan Yogyakarta. Belakangan, keberadaan baru berkembang ke kota-kota lain. Formulasi besar dari masifnya perkembangan pendidikan Islam di Indonesia memunculkan pertanyaan; bagaimana profil lulusan ahli-ahli agama IAIN/ STAIN/UIN sebagaimana yang dihendaki oleh para penggagasnya? Dari 
sinilah barangkali munculnya istilah ulama yang intelek, dan intelek yang ulama. Karena predikat ulama berarti menguasai hukum-hukum agama pribadi yang religius, intelek berarti memiliki kapasitas berpikir yang luas, kritis, dan memilki wawasan yang holistik tentang Islam.

Posisi IAIN, Sekolah Tinggi Agama Islam Negeri (STAIN), dan Universitas Islam Negeri (UIN), memiliki peran strategis dalam pengembangan pendidikan Islam ke depan jika dilihat dari ide pendiriannya. Tanggung jawab sebagai Perguruan Tinggi Agama Islam tidak kecil. Amanah pendirian berbagai perguruan tinggi itu mengemban misi mewujudkan serta mengarahkan lulusannya agar menjadi insan yang setia serta memiliki komitmen dan pengabdian yang tinggi terhadap agama yang dipelajari. Tantangan besar dihadapi lembaga pendidikan Islam itu dari pengaruh-pengaruh negatif dari efek globalisasi. Bila dirunut, jumlah lembaga pendidikan tinggi di Indonesia terdiri dari: 1) UIN berjumlah 6 lembaga dengan peserta didik sejumlah 71.402 dengan dosen 4.972 orang, 2) IAIN berjumlah 13 lembaga, peserta didik mencapai 52.027 dengan jumlah dosen 4.429 orang, 3) STAIN berjumlah 33 unit, peserta didik terdaftar sebanyak 52.149 dengan jumlah dosen 3.961 orang, 4) PTAIS sejumlah 539 lembaga dengan besaran peserta didik 394.489 dan jumlah dosen mencapai 22.407 orang. Dari seluruh jumlah pendidik, 42\% diantaranya belum memenuhi kualifikasi minimal yang ditetapkan standar nasional pendidikan.

\section{Rekonstruksi Pendidikan Islam untuk Membangun Masyarakat Etik}

Bertolak dari alur pikir konstruksi sejarah pendidikan Islam di atas, maka aspek-aspek pendidikan yang perlu ditanamkan kepada manusia menurut konsep pendidikan Islam adalah : (1) Aspek pendidikan ketuhanan, (2) Aspek pendidikan moral atau akhlak, (3) Aspek pendidikan akal dan ilmu pengetahuan serta keterampilan, (4) Aspek pendidikan fisik, dan (5) Aspek pendidikan kejiwaan. Aspek pendidikan ketuhanan adalah penanaman jiwa beragama yang kokoh meliputi akidah Islam dalam arti yang sesungguhnya, mampu melaksanakan perintah dan menjauhi larangan Tuhan. Pendidikan moral (akhlak) mewujudkan sifat dan tingkah laku terpuji serta menjauhi tingkah laku tercela. Pendidikan akal, ilmu pengetahuan, dan keterampilan, berkaitan dengan pencerdasan akal, membekali peserta didik dengan berbagai ilmu pengetahuan dari perennial knowledge maupun acquired knowledge. Sedangkan pendidikan keterampilan adalah memberikan kecakapan-kecakapan khusus kepada peserta didik. Pendidikan fisik, berkaitan dengan organ-organ jasmaniah, 
mengembangkan dan memeliharanya sebagai amanah yang diberikan Allah, agar manusia hidup dalam keadaan sehat untuk dapat dipergunakan sebagai sarana mengabdi kepada Allah. Aspek pendidikan kejiwaan berintikan agar setiap peserta didik memilki jiwa yang sehat dan terhindar dari segala macam penyakit kejiwaan. Berkenaan dengan itu, agar seseorang dapat menyesuaikan diri dengan dirinya sendiri, orang lain dan lingkungan masyarakatnya, maka mengedepankan akhlak sebagai salah satu tujuan pendidikan adalah keharusan.

Pendidikan akhlakul karimah (budi pekerti yang terpuji) menjadi lebih berhasil di lingkungan pesantren daripada lembaga pendidikan lainnya karena diterapkan dengan mengacu pada internalisasi nilai daripada instruksionalisasi teori. Di samping itu, pendidikan akhlak juga lebih banyak membutuhkan keteladanan. Sikap keteladanan itu masih amat terjaga di lingkungan pesantren hingga kini. Internalisasi nilai di pesantren terjadi sepanjang hari dan juga didukung adanya figur teladan moral (kiai) dan lingkungan yang kondusif. Inilah yang menjadikan inti pendidikan Islam menurut uraian di atas adalah upaya menyelamatkan hakikat dan martabat manusia itu sendiri dan sekaligus mengembangkan potensi-potensi yang dimilikinya sesuai dengan tuntunan agama Islam. Ironisnya, kondisi pendidikan Islam saat ini ibarat dalam titik nadir terendah. Dunia pendidikan Islam dewasa ini sedang mengalami banyak sekali tantangan. Persinggungan langsung dengan bidang-bidang di luar sistem pendidikan seperti politik, ekonomi, lingkungan hidup, sosial budaya, dan perkembangan ilmu pengetahuan dan teknologi, merubah paradigma pendidikan Islam di era modern. Saat ini, bangsa Indonesia telah dihadapkan pada banyak masalah dan tantangan yang berat, terutama setelah munculnya globalisasi budaya, etika, dan moral sebagai akibat dari kemajuan teknologi sehingga sumber-sumber nilai dalam masyarakat sulit dikontrol apalagi dihentikan.

Sebagai contoh, dunia pendidikan Indonesia dikejutkan oleh berbagai peristiwa. Misalnya bocornya soal soal ujian nasional (UN). Ketika peserta didik ingin meningkatkan kualitas dan mutu lulusan sekolah, justru mental kejujuran mereka menjadi minus. Di sisi lain, diakui adanya kecenderungan pendidikan Islam dari mulai jenjang pendidikan dasar hingga perguruan tinggi masih bersifat doktrinal. Ini yang menyebabkan pendidikan Islam belum sepenuhnya mampu membangun character building dan mengantarkan peserta didik menuju sikap kritis dan toleran. Padahal dari sisi tujuan utama, pendidikan Islam dilihat dari konsep al Quran dan Hadits adalah bertujuan 
untuk membentuk pribadi muslim yang unggul seutuhnya, mengembangkan seluruh potensi manusia baik yang berbentuk jasmani maupun rohani, menumbuhkan hubungan yang harmonis setiap pribadi manusia dengan Allah, manusia lainnya, dan alam semesta.

Pendidikan Islam sebagaimana dimaksud di atas bertolak dari pandangan Islam tentang manusia. Al Quran menjelaskan bahwa manusia itu makhluk yang mempunyai dua fungsi yang sekaligus mencakup dua tugas pokok utama. Fungsi pertama manusia adalah sebagai khalifah Allah di bumi. Makna ini mengandung arti bahwa manusia diberi amanah untuk memelihara, merawat, memanfaatkan, serta melestarikan alam raya. Fungsi kedua, manusia adalah makhluk Allah yang ditugasi untuk menyembah dan mengabdi kepadaNya. Selain itu, manusia adalah makhluk yang memiliki potensi lahir dan batin. Potensi lahir adalah unsur fisik yang dimiliki oleh manusia tersebut. Sedangkan potensi batin adalah potensi yang dimiliki manusia terkait dengan kemampuannya menerima ajaran, nilai, dan norma-norma agama.

Uraian di atas dipertegas dalam Firman Allah:

Tidak wajar bagi seseorang manusia yang Allah berikan kepadanya Al Kitab, Hikmah dan kenabian, lalu Dia berkata kepada manusia: "Hendaklah kamu menjadi penyembah-penyembahku bukan penyembah Allah." Akan tetapi (dia berkata): "Hendaklah kamu menjadi orang-orang rabbani, karena kamu selalu mengajarkan Al kitab dan disebabkan kamu tetap mempelajarinya (QS Ali Imron: 79).

Di pandang dari sudut potensi fitrahnya manusia memiliki potensi qalbiyah, (afektif), potensi aqliyah (kognitif), dan potensi jasadiyah (psikomotorik). Dengan demikian, pengembangan pendidikan Islam harus memenuhi ketiga aspek potensi tersebut. Sedangkan ditinjau dari segi fungsinya sebagai khlalifah, maka aspek yang perlu dikembangkan adalah aspek pemahaman, penguasaan, dan tanggung jawab terhadap kelestarian alam raya. Berkenaan dengan itu maka perlu dikembangkan aspek pendidikan ilmu pengetahuan dan aspek pendidikan moral, serta aspek keterampilan pengelolaan alam raya Ditinjau dari segi fungsi manusia sebagai hamba, maka aspek yang penting untuk didikan adalah aspek pendidikan ketuhanan (Tauhid). Mengaca pada tradisi periodesasi Abasiyah, pola pendidikan Islam memiliki banyak varian, dan hampir semua lembaga pendidikan waktu itu mendapatkan dukungan penuh dari pemerintah dalam bidang pendanaan. Sehingga, penuntut ilmu tidak dipungut biaya sama sekali. Pada akhirnya, ilmu pengetahuan dan teknologi berkembang pesat. Oleh sebab itu, pembacaan sketsa sejarah pendidikan 
Islam pada masa lalu menjadi ibrah bagi generasi saat ini serta menjadi pola pembentukan pendidikan Islam masa depan.

\section{Simpulan}

Sejarah pendidikan Islam mengekspresikan berbagai model-model pendidikan bagi umat Islam dalam berbagai belahan dunia. Sejarah mengandung muatan Islam yang sarat dengan pengembangan pendidikan yang dicirikan dengan kedalaman dalam penghayatan spirit-spirit keagamaan serta penghargaan atas semangat kemanusiaan. Ini yang membuat sejarah sebagai ibroh dari berbagai realitas model pendidikan Islam.

Realitas pendidikan Islam yang selama ini terlihat masih dalam bayangbayang pendidikan Barat perlu merekonstruksi ulang model pendidikan yang dianutnya. Apalagi di tengah era globalisasi merevitalisasi nilai-nilai yang membangun pendidikan Islam perlu disemaikan, dibudidayakan dan dijaga. Karena itu, sepatutnya dengan membaca sejarah pendidikan Islam yang bermuatan progresif, dinamis, dan diharapkan pendidikan Islam dapat mampu menjawab tuntuntan perkembangan zaman. Di titik inilah perumusan model pendidikan Islam sesungguhnya menjadi aktivitas yang tidak pernah terhenti. Oleh karena itu, sejarah pendidikan Islam hadir untuk menumbuhkan spiritualitas dan ghiroh para pendidik dalam mengembangkan sistem pendidikan yang islami.

Pada akhirnya, nilai-nilai sejarah tersebut menjadi bagian penting dalam merekonstruksi ulang sistem pendidikan Islam. Ketika historisme Islam bersinggungan dengan nilai-nilai modernitas, maka secara substantif karakter dasar pendidikan Islam harus terus terjaga meski secara model penyelenggaraannya mengalami metamorfosis dari masa ke masa. Dengan demikian, sejarah dalam pendidikan Islam bukan hanya sebuah narasi panjang yang tak bermakna, melainkan penuh dengan muatan hikmah sekaligus puing-puing yang dapat direkonstruksi kembali menjadi sistem pendidikan Islam yang komprehensif dalam berbagai putaran zaman.

\section{Daftar Pustaka}

Black, Antony. 2001. Pemikiran Politik Islam. Jakarta: Serambi.

Departemen Agama RI. 2009. Profil Pendidikan Islam Tahun 2009. Jakarta: Depag.

Direktorat Jenderal Kelembagaan Agama Islam Kementerian Agama. 2005. 
Rekonstruksi Sejarah Pendidikan Islam di Indonesia. Jakarta: Departemen Agama RI.

Nasr, Sayyed Hossein. 1978. Science and Civilization in Islam. New York: New American Library.

Nizar, Samsul. 2007. Sejarah Pendidikan Islam. Jakarta: Kencana.

Zuhairini. 1994. Sejarah Pendidikan Islam. Jakarta: Bumi Aksara. 